\title{
Development of geopolymer using industrial waste materials
}

\author{
Gábor Mucsi, János Lakatos, Zoltán Molnár, Roland Szabó \\ University of Miskolc, Miskolc Egyetemváros, 3515, Miskolc, Hungary
}

\begin{abstract}
Coal burned thermal power plants are producing large amounts of solid waste, fly ash. The disposal of this waste is a huge environmental problem at this moment. Generally, fly ash particles are very fine $(<100 \mu \mathrm{m})$ and mainly round shaped and glassy materials form an outer shell on it. According to several authors the attrition or grinding of this shell improves the activity of the fly ash. This paper deals with the laboratory investigation of ground fly ash based geopolymer. This material can be applied in many fields, mainly in the construction industry, e.g. non-structural elements, concrete, pavements and products, containment and immobilization of toxic, hazardous and radioactive wastes, advanced structural tooling and refractory ceramics, and fire resistant composites used in buildings, etc...

In this study, the main process engineering properties of the raw materials, such as particle size distribution, moisture content, density and specific surface area are shown. Beside fly ash, red mud in different rate was used to prepare geopolymer. Systematic experimental series were carried out in order to optimize the preparation process. The particle size distribution of fly ash was measured by laser diffraction, the structure of fly ash and geopolymer was determined by Fourier Transformed Infrared Spectroscopy (FT-IR). The strength of the formed geopolymers was characterized by the uniaxial compressive strength. Additionally, leaching tests were carried out to monitor the stability of the main element of the fly ash. The product properties were studied as function of fly ash fineness.

As a result of the investigation it was found that the geopolymer strength increased as function of fly ash fineness. Furthermore, it was established that the red mud had a positive effect on geopolymer strength. Therefore, the synergetic application of the above wastes is of good potential to create an industrial final product. Of course, several further experimental work is necessary to study the system from environmental point of view.
\end{abstract}

Keywords: fly ash; red mud; geopolymer; mechanical activation.

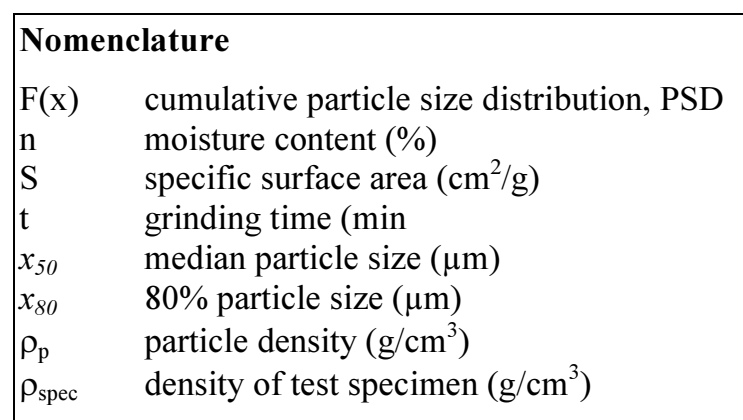

\section{Introduction}

Geopolymers are amorphous alumino silicates which can be produced by the reaction between silica and alumino silicate in alkaline medium $(\mathrm{NaOH}$ and/or $\mathrm{KOH})$ at ambient or elevated $\left(30-100{ }^{\circ} \mathrm{C}\right)$ temperature. Due to its simple, energy efficient and eco-friendly production method, excellent durability and good mechanical properties geopolymers can replace conventional materials from low tech application (building industry, waste immobilisation) to high tech industry (ceramics with special properties, composites). Every material is suitable for geopolymer production which contains silica and alumina bearing phases, like primary (for example metakaolin) or secondary (fly ash, steel slag, red mud, etc) raw materials [1].

Corresponding author: Gábor Mucsi. E-mail address: ejtmucsi@uni-miskolc.hu http://dx.doi.org/10.3846/enviro.2014.039

(C) 2014 The Authors. Published by VGTU Press. This is an open-access article distributed under the terms of the Creative Commons Attribution License, which permits unrestricted use, distribution, and reproduction in any medium, provided the original author and source are credited. 
Fly ash is a potential raw material for geopolymers, thanks to the presence of $\mathrm{SiO}_{2}$ and $\mathrm{Al}_{2} \mathrm{O}_{3}$ as the main components [2]. Limiting factor which obstructs the use of fly ash for geopolymerisation it is low reactivity. The reactivity of fly ash depends on its particle size distribution and the amount and composition of glassy phase [3-7]. Low reactivity of fly ash results in slow binding and early strength development. Many times the dissolution of fly ash did not finish before the final hardened structure was formed [3-7]. It has been proven that calcined materials like granulated blast furnace slag, fly ash and metakaolin (which are mainly amorphous) has higher reactivity during geopolymerisation reaction unlike uncalcined materials [1]. It can be explained that calcination activates materials from crystalline to amorphous structure and extra energy stored in them [1].

Somna et al. [8] studied $\mathrm{NaOH}$-activated ground fly ash geopolymers, cured at room temperature. Ground fly ash with a median particle size of $10.5 \mu \mathrm{m}$, was used as raw material mixed with $\mathrm{NaOH}$ as an alkali activator. Results indicated that ground fly ash gave higher strength geopolymer paste compared to original fly ash. The compressive strengths at 28 days of 20.0-23.0 MPa were obtained.

Paul et al. [9] carried out high energy ball milling of class F fly ash in order to convert it into nanostructured material. They found that the surface of the produced nano size fly ash has become more active as it was observed from FTIR studies. Morphological studies revealed that the surface of the nano structured fly ash is more uneven and rough and shape is irregular, as compared to fresh fly ash which are mostly spherical in shape. They achieved significant reduction in crystallinity in high energy milled fly ash after 60 hours residence time.

$\mathrm{Fu}$ et al. [10] investigated the physical-chemical characteristics of mechanically-treated circulating fluidized bed combustion (CFBC) fly ash. The water requirement decreases with prolonged grinding time, and slightly increases during the last stage of grinding. The $\mathrm{pH}$ of ground CFBC fly ash is greater than that of the original CFBC fly ash, indicating that ground samples react more rapidly with water. The intensity of the crystalline phases of ground CFBC fly ash decreases, while the half peak width of ground CFBC fly ash increases with prolonged grinding time, which means that ground fly ash has a higher reactivity than the original fly ash.

Hounsi et al. [11] investigated the influence of mechanical activation of raw kaolin on the final compressive strength of as-obtained geopolymers. Mechanical activation was performed by dry ball-milling of raw kaolin at $250 \mathrm{rpm}$ for $1 \mathrm{~h}$. Mechanical activation was performed to improve mechanical properties. Results showed that without mechanical activation, the optimal curing condition was $24 \mathrm{~h}$ at $70^{\circ} \mathrm{C}$ and the compressive strength was $15 \mathrm{MPa}$ after 28 days of ageing. Under mechanical activation, improvement of the compressive strength was obtained with a curing time of $72 \mathrm{~h}$ at $70{ }^{\circ} \mathrm{C}(35 \%$ increase) or with a curing temperature of $100{ }^{\circ} \mathrm{C}(76 \%$ improvement). The formation of alkaline aluminosilicate gels and new crystalline hydrated phases controlled the strength development of geopolymers while the occurrence of carbonated species was responsible for the degradation of mechanical properties.

Kumar and Kumar [12] investigated red mud, a residue of Bayer's process to be used synergistically with fly ash to develop geopolymer. An improvement in intensity of reaction was observed with the red mud addition at all replacement level but improvement in setting time and compressive strength was observed only in the samples containing 5-20\% red mud. Structural characterization revealed that rate of reaction was dependent on the $\mathrm{NaOH}$ concentration but the development of mechanical properties were related to the compact microstructure which was developed due to the combined effect of $\mathrm{NaOH}$ concentration, solubility of silicates and the presence of iron oxides. Based on scientific understanding, paving blocks using $10 \%$ and $20 \%$ red mud was developed.

Van Riessen et al. [13] examined various industrial residues to manufacture geopolymers, these relatively new cements have the ability to bind a range of contaminants. As the Bayer process could achieve significant process impurity removal by utilisation of plant liquor, synergy between the alumina and geopolymer industries could be achieved. Geopolymers with a $\mathrm{Si} / \mathrm{Al}$ ratio of 2.3 and a $\mathrm{Na} / \mathrm{Al}$ ratio of 0.8 were targeted. With only synthetic plant liquor as the alkali activator, geopolymers with a mean compressive strength of $33 \mathrm{MPa}$ were synthesized, while use of processed plant liquor resulted in compressive strengths of $43 \mathrm{MPa}$.

The aim of the present research reported in this study primary is to study the effect of grinding on the structure of fly ash based geopolymer and to examine the relation between fly ash fineness and geopolymer compressive strength. Additional goal was to investigate the dependence of strength on the concentration of alkaline activator.

\section{Materials and methods}

The lignite fly ash sample used for laboratory experiments is originated from Mátra Power Station (Visonta) which mineralogical composition beside red mud (Almásfüzitö) sample can be found in Table 1. The mineral composition of the fly ash was determined by a Bruker D8 Advance XRD powder diffractometer (Cu-Ka radiation, $40 \mathrm{kV}, 40 \mathrm{~mA}$ ) in BraggBrenanto geometry (with detector side graphite monochromator). To decrease planar orientation sample bin rotated in sample plane. X-ray diffraction patterns were recorded in $2-70^{\circ}(2 \theta)$ range. Sample crystalline phases are detected by Bruker DiffracPlus software package in its EVA module ICDD PDF-2 (2005) database is employed for search/matching of phases. Quantitative evaluation was made by Rietveld fitting method on TOPAS3 software using FPM based instrument convolution. Structural data originated from AMCSD database.

The alkaline activator used for the preparation of geopolymer was $\mathrm{NaOH}$ solution in different concentration $(6,8,10,12$ and $14 \mathrm{M})$. 
Table 1. Mineralogical composition of fly ash and red mud

\begin{tabular}{lcll}
\hline \multicolumn{3}{c}{ Lignite fly ash } & \multicolumn{2}{c}{ Red mud } \\
\hline Mineral & {$[\%]$} & Mineral & {$[\%]$} \\
Quartz & 20,34 & Hematite & 45,47 \\
Maghemite & 4,22 & Calcite & 7,93 \\
Hematite & 3,91 & Kankrinite & 35,48 \\
Anhidrite & 7,08 & Lime & 1,8 \\
Albite & 4,71 & Gibbsite & 9,32 \\
Albite K0.16 & 5,58 & & \\
Lime & 1,61 & & \\
Amorph & 52,5 & & \\
\hline
\end{tabular}

The particle size distribution (PSD) and specific surface area (SSA) are of great importance from the point of view of reactivity. The particle size distribution of the raw and the ground materials was measured by HORIBA LA-950V2 laser diffraction particle size analyzer in wet mode using distilled water as dispersing media and sodium-pyrophosphate as dispersing agent applying the Mie-theory as evaluation method. The specific surface area (SSA) was calculated using PSD data by the laser sizer software. The particle size distribution of the initial raw materials can be seen in Figure 1. The red mud sample can be characterized with a much finer particle size distribution than the fly ash sample.

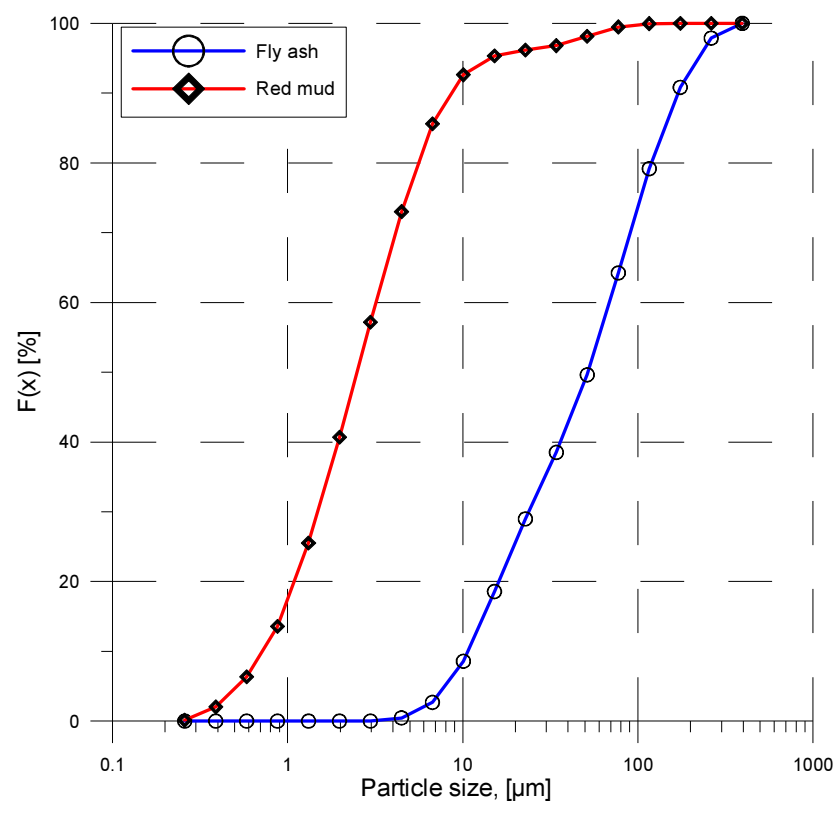

Fig. 1. Particle size distribution of fly ash and red mud samples

The particle density $\left(\rho_{\mathrm{p}}\right)$ was determined by pycnometer method using alcohol as media. Moisture content (n) of fly ash was very low $0.27 \%$, however that of the red mud was significantly higher $33.64 \%$ measured in drying oven at $105^{\circ} \mathrm{C}$ until constant mass. The drying time required to achieve constant mass varied depending on the type of the material. In most cases, an overnight (12-16 h) drying period is sufficient.

The structure of the fly ash and the geopolymer product was investigated by FT-IR. Stretching and bending vibrations of chemical bonds in samples induced by infra range electromagnetic waves detected by JASCO FT-IR 4200 type Fourier Transformed Infrared Spectrometer in reflection mode, a diamond ATR was used. Five tests were carried out parallel from each sample. One spectrum represents 32 FT-IR measurements with $4 \mathrm{~cm}^{-1}$ resolution number. The results are shown in Results and discussion Chapter.

The elemental analyses of the samples were carried out using ICP-OES followed alkaline ignition and dissolution by hydrochloric-acid.

\section{Experimental}

The mechanical activation experiments under dry condition were carried out in a conventional tumbling laboratory ball mill with the size of $\emptyset 303 \times 305 \mathrm{~mm}$ internal diameter (smooth walled), with steel balls (max ball size $50 \mathrm{~mm}$ ) as grinding media. The mill filling ratio of the grinding media was $30 \mathrm{~V} / \mathrm{V} \%$, the material filling ratio was $110 \mathrm{~V} / \mathrm{V} \%$. The operating revolution 
number to critical revolution number (e) was $80 \%$. Residence time of mechanical activation was $5,10,20,30$ and 60 minutes.

Geopolymer specimens made by mixing raw- or ground fly ash and $\mathrm{NaOH}$ solution using 0.67 liquid/solid ratio. Mixtures was placed to pre- oiled moulds and compacted by vibration. The compacted mixture was kept in moulds for 24 hours insulated at ambient temperature, before unsealed the specimens. It is followed by heat curing at $90{ }^{\circ} \mathrm{C}$ for 6 hours. After heat curing left the specimens cooled down to ambient temperature. The mechanical test was carried out by Compression Testing Machine in the age of 7 days.

Leaching tests were performed by distilled water and different strength acidic solutions ( $1 \mathrm{~mol} / 1 \mathrm{acetic}-\mathrm{acid}, 1 \mathrm{~mol} / \mathrm{l}$ nitric-acid).

\section{Results and discussion}

\subsection{Mechanical activation of fly ash}

Mechanical activation through ultrafine milling is an effective procedure where an improvement in technological processes can be attained via a combination of several bulk and surface effects, which influence the properties of applied minerals [14, 15]. The primary effect of mechanical activation by grinding in our case was the particle size decrease and specific surface area increase, which is summarized in Table 2. After 60 minutes grinding in a ball mill $11.6 \mu \mathrm{m}$ median particle size was achieved from the initial value of $52.04 \mu \mathrm{m}$, indicating a 4.49 size reduction rate. Additionally, the "outer" specific surface area increase was significant; from $1152.07 \mathrm{~cm}^{2} / \mathrm{g}$ it reached $5425.55 \mathrm{~cm}^{2} / \mathrm{g}$ due to ball milling.

Table 2. Characteristic particle size values and specific surface area of raw and ground fly ash

\begin{tabular}{|l|l|l|l|l|l|l|}
\hline Characteristic particle size & Raw fly ash & $\begin{array}{l}5 \text { min ground fly } \\
\text { ash }\end{array}$ & $\begin{array}{l}10 \text { min ground } \\
\text { fly ash }\end{array}$ & $\begin{array}{l}20 \text { min ground } \\
\text { fly ash }\end{array}$ & $\begin{array}{l}30 \text { min ground } \\
\text { fly ash }\end{array}$ & $\begin{array}{l}60 \text { min ground } \\
\text { fly ash }\end{array}$ \\
\hline $\mathrm{x}_{50}(\mu \mathrm{m})$ & 52.04 & 43.82 & 29.84 & 21.29 & 18.94 & 11.6 \\
\hline $\mathrm{x}_{80}(\mu \mathrm{m})$ & 119.32 & 91.72 & 69.67 & 49.09 & 43.58 & 27.9 \\
\hline Specific surface area $\left(\mathrm{cm}^{2} / \mathrm{g}\right)$ & 1152.07 & 1219.3 & 1500.29 & 1738.43 & 1928.9 & 5425.55 \\
\hline
\end{tabular}

The variation of particle density $\left(\rho_{p}\right)$ of the raw and ground fly ash can be found in Figure 2 . Significant increase in the particle density was observed as function of grinding time. Namely, from the initial value of $1.94 \mathrm{~g} / \mathrm{cm}^{3}$ the density reaches $2.26 \mathrm{~g} / \mathrm{cm}^{3}$ after 20 minutes grinding time. It can be explained by the porous structure of fly ash.

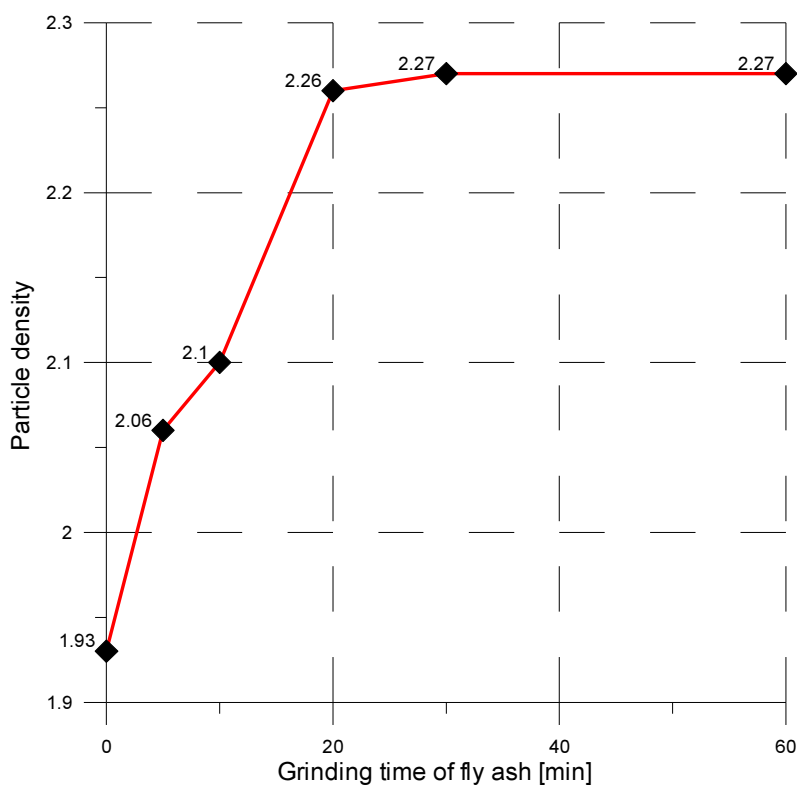

Fig. 2. Particle density as function of grinding time (t)

A plateau in the particle density-grinding time curve is reached after 20 min grinding time, after it only slight increase was detected in spite of that the material fineness is changed remarkably. It can be found that the material density of the investigated fly ash is $2.27 \mathrm{~g} / \mathrm{cm}^{3}$. 


\subsection{Ground fly ash based geopolymer}

The effect of grinding fineness on the geopolymer strength was carried out using $6 \mathrm{M}$ concentration $\mathrm{NaOH}$ solution, the geopolymer paste was prepared from $40 \mathrm{~m} / \mathrm{m} \%$ alkaline activator ( $\mathrm{NaOH}$ solution) and $60 \mathrm{~m} / \mathrm{m} \%$ mechanically activated fly ash. The density and uniaxial compressive strength of the geopolymer product was determined after 7 days of aging. These results can be found in Figure 3. Based on the specimen density $\left(\rho_{\text {spec }}\right)$ values, it can be concluded that there is no difference between the $30 \mathrm{~min}$ and $60 \mathrm{~min}$ ground fly ash based geopolymer $\left(1.35 \mathrm{~g} / \mathrm{cm}^{3}\right)$. This is in correlation with fly ash particle density results (Fig. 2). However, the compressive of the $60 \mathrm{~min}$ ground fly ash based geopolymer was $21.5 \%$ higher than that of the product consisting 30 min ground fly ash.

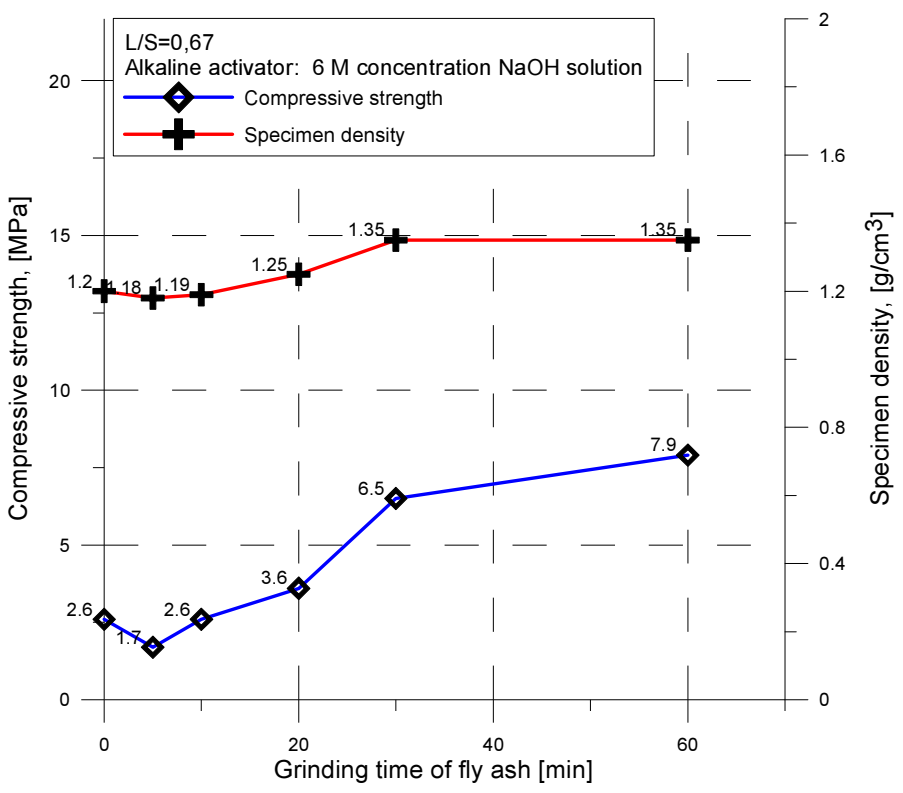

Fig. 3. Effect of grinding time of fly ash on the compressive strength and density of geopolymer test specimen

The highest geopolymer compressive strength was 7.9 MPa using $6 \mathrm{M} \mathrm{NaOH}$ solution as alkaline activator and 60 min ground fly ash.

\subsection{The $\mathrm{NaOH}$ concentration}

The optimal grinding time was determined previously which was found to be 60 minutes. Therefore this state of activation was used in the following experimental steps. The effect of concentration of sodium-hydroxide was examined using $6,8,10$, 12 and $14 \mathrm{M}$ solution, heat treated at $60^{\circ} \mathrm{C}$ and $90^{\circ} \mathrm{C}$ temperature.

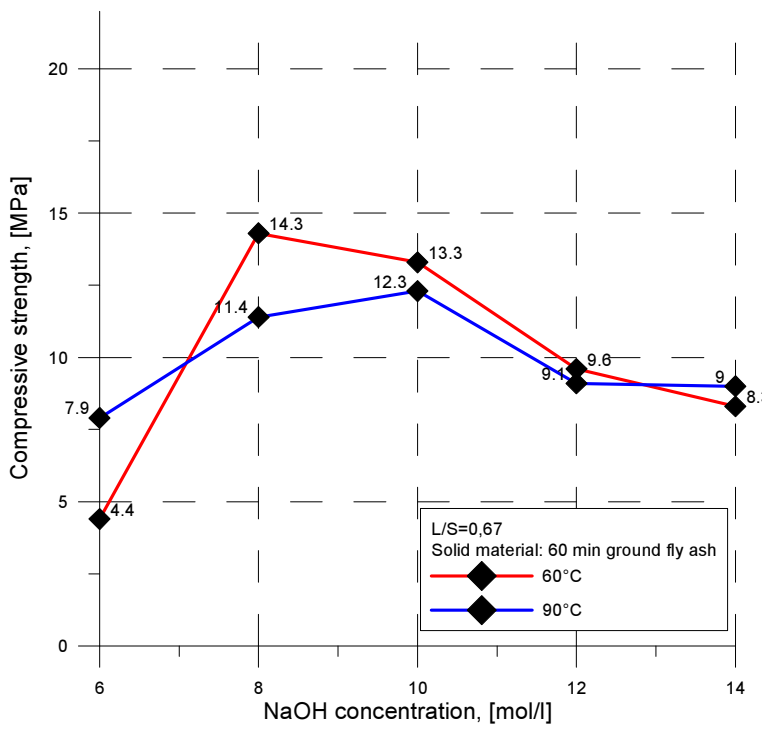

(a)

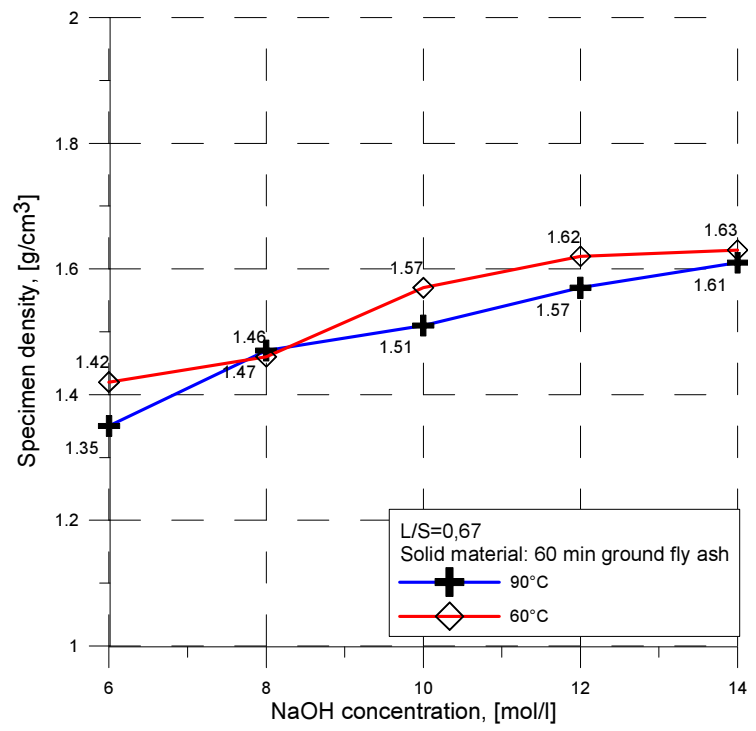

(b)

Fig. 4. Effect of $\mathrm{NaOH}$ concentration on geopolymer strength (a) and density of test specimen (b) using ground fly ash 
From Figure 4 it can be observed that the highest compressive strength values was found using 8 and $10 \mathrm{M} \mathrm{NaOH}$ solution at both heat treated geopolymer. The most mechanical stable geopolymer was reached at $60{ }^{\circ} \mathrm{C}$ temperature using the $8 \mathrm{M}$ concentration activator, which uniaxial compressive strength was $14.3 \mathrm{MPa}$. However, it is interesting that there is no correlation between compressive strength and density. Namely the density was only $1.46 \mathrm{~g} / \mathrm{cm}^{3}$ in this case, after this point it reached 1.63 as a maximum but no strength increased was observed. To understand the phenomenon, structure of the geopolymer was investigated by FT-IR.

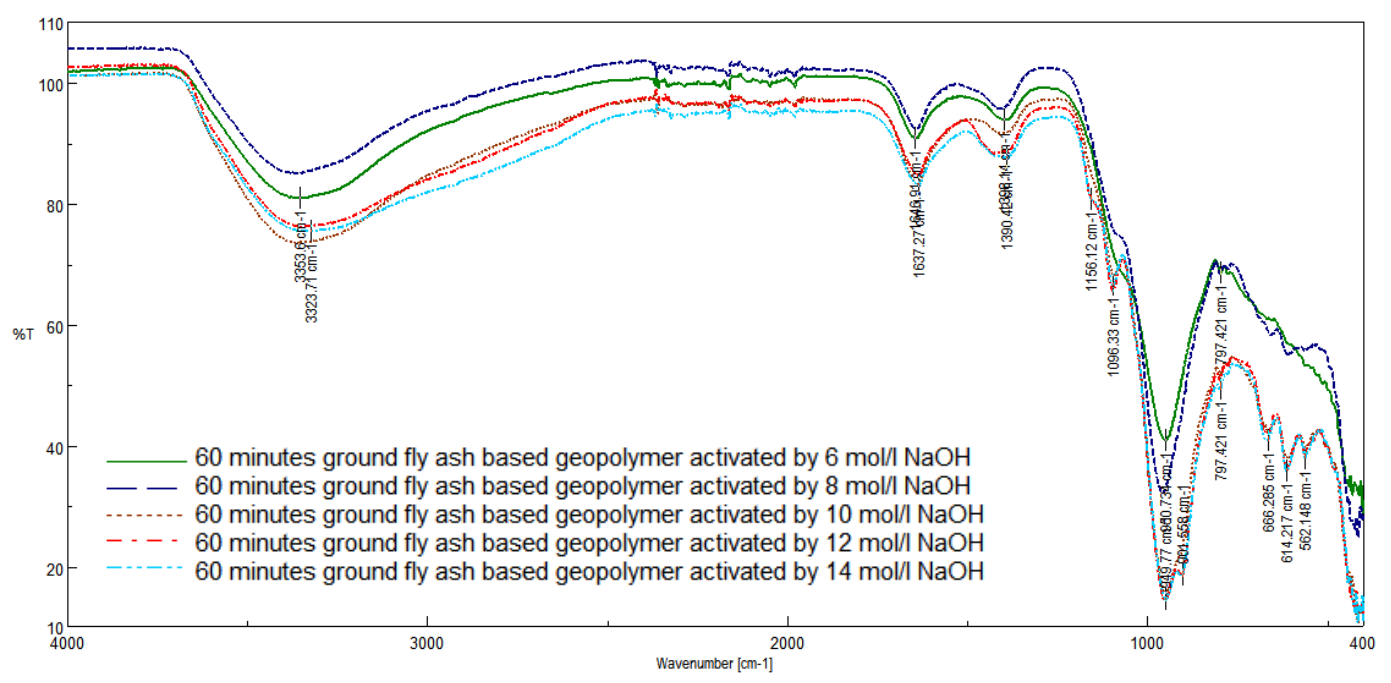

Fig. 5. FT-IR spectras of ground fly ash based geopolymer treated at $90{ }^{\circ} \mathrm{C}$

The FTIR spectra of ground fly ash based geopolymer activated by different concentration $\mathrm{NaOH}$ solution can be seen in Figure 5. The peaks at $6 \mathrm{~mol} / 1$ case corresponds to the presence of amorphous aluminosilicate gel $\left(950 \mathrm{~cm}^{-1}, 797 \mathrm{~cm}^{-1}\right.$ assymetric and symmetric stretching vibraton of Si-O-Si and Al-O-Si bonds) and carbonate (1398 $\mathrm{cm}^{-1}$, O-C-O stretching vibration). Peaks at $3350 \mathrm{~cm}^{-1}$ and $1647 \mathrm{~cm}^{-1}$ related to $-\mathrm{OH}, \mathrm{HOH}$ stretching and bending vibration. By increasing $\mathrm{NaOH}$ solution concentration new peaks was observed; $1156 \mathrm{~cm}^{-1}$ and $901 \mathrm{~cm}^{-1}$ corresponds to asymmetric stretching vibration of $\mathrm{Si}-\mathrm{O}-\mathrm{Si}$, Al-O-Si bonds, $797 \mathrm{~cm}^{-1}, 666 \mathrm{~cm}^{-1}, 614 \mathrm{~cm}^{-1}$ and $562 \mathrm{~cm}^{-1}$ related to symmetric stretching vibration of Si-O-Si and Al-O-Si. These differences prove that structural changes are between the geopolymers, which can give answer the cause of compressive strength decreasing. Probably, the formed geopolymer structure is not appropriate due to high $\mathrm{Na}^{+}$presence, or the formed geopolymer structure partially dissolved in the high alkaline conditions.

\subsection{Red mud additive}

During the preparation of the geopolymer paste red mud was added in 5, 10, 15, 20, 25 and $30 \%$ for the solid mass of fly ash. Alkaline activator $\mathrm{NaOH}$ with $6 \mathrm{M}$ concentration was used in different ratio depending on the workability of the paste, namely for geopolymer paste containing $5 \%$ red mud the activator was added in $40 \mathrm{~m} / \mathrm{m} \%$, for that of 10,15 and $20 \%$, the activator was added in $35 \mathrm{~m} / \mathrm{m} \%$, finally for 25 and $30 \%$, the $\mathrm{NaOH}$ solution was added in $30 \%$.

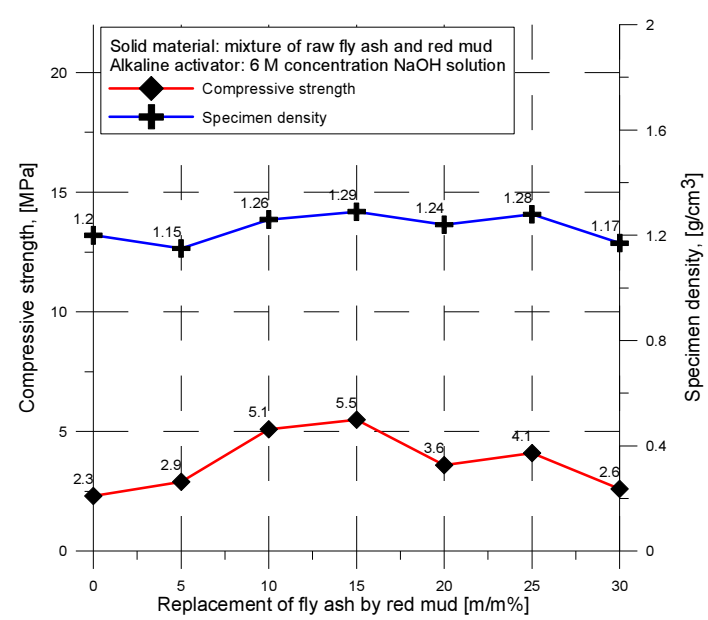

(a)

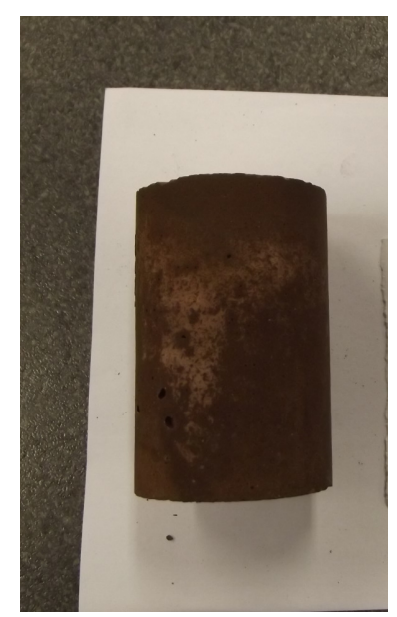

(b)

Fig. 6. a) Effect of red mud content on the geopolymer strength and density of specimen, b) Geopolymer specimens containing red mud ( $80 \%$ fly ash and $20 \%$ red mud) 
The results of experiments can be found in Figure 6. Regarding the density values of geopolymer product the values are fluctuating in the range of 1.15 and $1.29 \mathrm{~g} / \mathrm{cm}^{3}$. However, the strength values have a maximum point at $15 \mathrm{~m} / \mathrm{m} \% \mathrm{red} \mathrm{mud}$ content, which was $5.5 \mathrm{MPa}$.

The geopolymer test specimens containing $20 \%$ red mud beside $80 \%$ fly ash can be seen in Figure 6 b. It can be observed that the characteristic red color of red mud will be dominant in the final product. It might be an advantage if commercialized product will be manufactured.

\subsection{Leaching of main element of fly ash}

The raw and mechanically activated (for 5, 10, 20, 30 and $60 \mathrm{~min}$ ) fly ash was treated in 1, 5 and $10 \mathrm{M} \mathrm{NaOH}$ solution. After the phase separation the elemental content was determined of the solution phase. Based on the Figure 7 two main conclusions can be drawn: the effect of grinding can be seen clearly. The quantity of alkaline soluble silica and aluminium is increasing as function of grinding time.

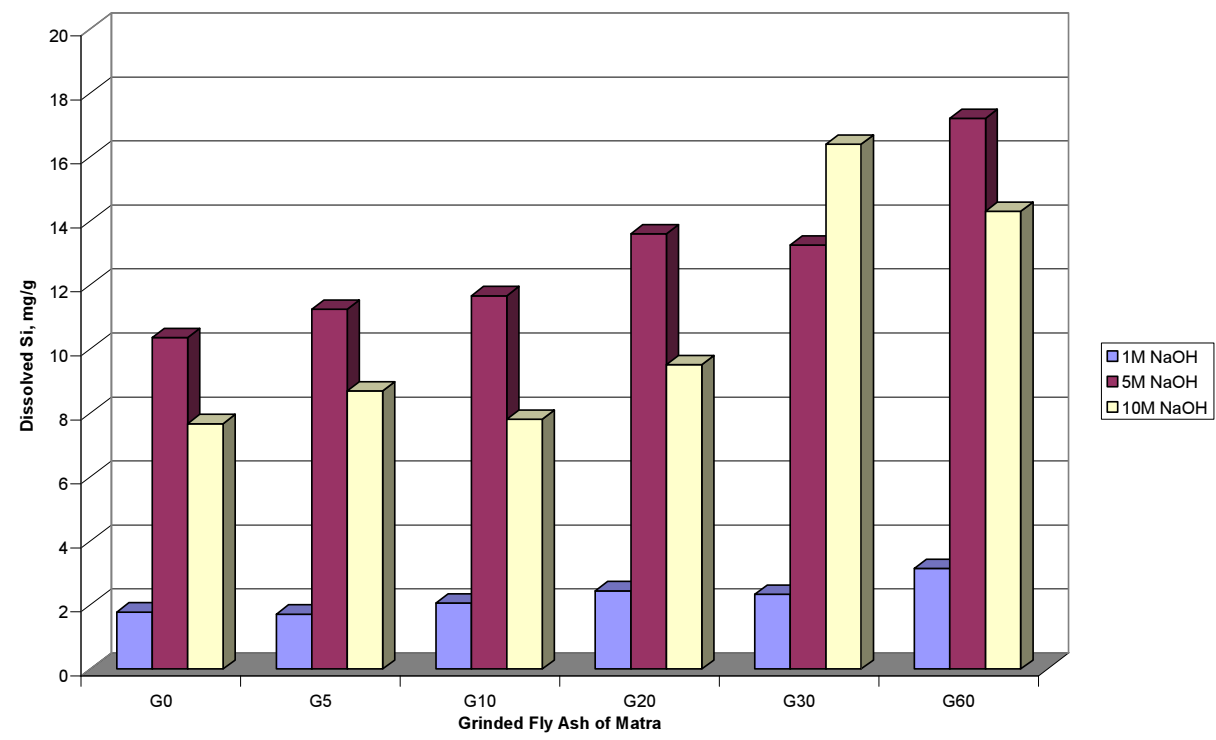

Fig. 7. Leaching of Si from mechanically activated fly ash (G0 - raw fly ash, G60 - 60 min grinding) at different concentration $\mathrm{NaOH}$ solution $(1,5$ and $10 \mathrm{M})$

The second observation is that as function of alkaline concentration, the quantity of leached silica and aluminium is increasing only until a certain alkaline concentration, after that point it drops down (see $10 \mathrm{M} \mathrm{NaOH}$ results).

\section{Conclusions}

Based on the experimental results presented above the following conclusions can be drawn:

- The mechanical activation by ball mill caused significant increase in material fineness $\left(5425.55 \mathrm{~cm}^{2} / \mathrm{g}\right)$ and in particle density of the fly ash investigated.

- The grinding fineness improved the geopolymer uniaxial compressive strength from the initial 2.6 MPa up to 7.9 MPa.

- The optimum $\mathrm{NaOH}$ concentration of the alkaline activator was $8 \mathrm{M}$ for $60{ }^{\circ} \mathrm{C}$ heat treatment (maximum compressive strength was $14.3 \mathrm{MPa}$ ) and $10 \mathrm{M}$ for $90{ }^{\circ} \mathrm{C}$.

- FT-IR spectras shows structural differences between ground fly ash based geopolymer activated by different concenctrated $\mathrm{NaOH}$ solution. The cause of compressive strength decreasing is persumably that the formed geopolymer structure is not appropriate due to high $\mathrm{Na}^{+}$presence, or the formed geopolymer structure partially dissolved in the high alkaline conditions.

- The addition of red mud in different portion tailored the compressive strength of the final product until a certain concentration $(20 \mathrm{~m} / \mathrm{m} \%)$, after started to decrease. The maximum strength reached was $5.5 \mathrm{MPa}$.

- The quantity of alkaline soluble silica and aluminium of fly ash is increasing as function of grinding time.

- Further goal of the research is to carry out leaching test of toxic component of geopolymer and its raw materials.

\section{Acknowledgements}

The research work was performed primary in the framework of a TÉT Indo-Hungarian collaboration project entitled "Tailoring of fly ash based geopolymer properties by mechanical activation (GEOPOL10)" and project GOP-1.1.1-11-2012- 
0379 at the Centre of Excellence in Sustainable Natural Resource Management at the Faculty of Earth Science and Engineering, University of Miskolc.

\section{References}

[1] Komintsas, K.; Zaharaki, D. 2007. Geopolymerisation: A review and prospects for the mineral industry, Mineral Engineering 20 , $1261-1277$. http://dx.doi.org/10.1016/j.mineng.2007.07.011

[2] Davidovits, J. 2011. Geopolymer chemistry and application. Published by: Institut Geopolimére 16 rue Galilée F-02100 Saint-Quentin France, ISBN: $9782951482050,283,286$.

[3] S. Kumar, R. Kumar. 2011. Mechanical activation of fly ash: Effect on reaction, structure and properties of resulting geopolymer, Ceramics International 37, 533-541. http://dx.doi.org/10.1016/j.ceramint.2010.09.038

[4] R. Kumar, S. Kumar, S.P. Mehrotra. 2007. Towards sustainable solutions for fly ash through mechanical activation. Resources, Conservation and Recycling 52: 157-159. http://dx.doi.org/10.1016/j.resconrec.2007.06.007

[5] Kumar, S.; Kumar, R.; Alex, T. C.; Bandopadhyay, A.; Mehrotra, S. P. 2007. Influence of reactivity of fly ash on geopolymerisation, Advances in Applied Ceramics 106(3): 120-127. http://dx.doi.org/10.1179/174367607X159293

[6] Temuujin, J.; Williams, R. P.; van Riessen, A. 2009. Effect of mechanical activation of fly ash on the properties of geopolymer cured at ambient temperature, Journal of Material Processing Technology 209: 5276-5280. http://dx.doi.org/10.1016/j.jmatprotec.2009.03.016

[7] Mucsi, G.; Csőke, B.; Molnár, Z. 2010. Laboratory investigation of geopolymer production from industrial waste materials, in Proceedings of the XII ${ }^{\text {th }}$ International Mineral Processing Symposium 6-8. October 2010. Cappadocia Nevsehir, Turkey ISBN: 978-975-491-295-1, 1235-1242.

[8] Kiatsuda Somna, Chai Jaturapitakkul Puangrat Kajitvichyanukul, Prinya Chindaprasirt. 2011. NaOH-activated ground fly ash geopolymer cured at ambient temperature, Fuel 90(6): 2118-2124. http://dx.doi.org/10.1016/j.fuel.2011.01.018

[9] Paul, K. T.; Satpathy, S. K.; Manna, I.; Chakraborty, K. K.; Nando, G. B. 2007. Preparation and Characterization of Nano structured Materials from Fly ash: A Waste from Thermal Power Stations, by High Energy Ball Milling, Nanoscale Res Lett 2: $397-404$. http://dx.doi.org/10.1007/s11671-007-9074-4

[10] Xiaoru, F.; Qin, L.; Jianping Z.; Guanghong, S.; Feihu, L. 2008. The physical-chemical characterization of mechanically-treated CFBC fly ash, Cement \& Concrete Composites 30: 220-226. http://dx.doi.org/10.1016/j.cemconcomp.2007.08.006

[11] Hounsi, A. D.; Lecomte-Nana, G. L.; Djétéli, G.; Blanchart, P. 2013. Kaolin-based geopolymers: Effect of mechanical activation and curing process, Construction and Building Materials 42: 105-113. http://dx.doi.org/10.1016/j.conbuildmat.2012.12.069

[12] Anuj, K.; Sanjay, K.. 2013. Development of paving blocks from synergistic use of red mud and fly ash using geopolymerisation, Construction and Building Materials 38: 865-871. http://dx.doi.org/10.1016/j.conbuildmat.2012.09.013

[13] Arie van Riessen, Evan Jamieson, Catherine S. Kealley, Robert D. Hart, Ross P. Williams. 2013. Bayer-geopolymers: An exploration of synergy between the alumina and geopolymer industries, Cement and Concrete Composites 41: 29-33. http://dx.doi.org/10.1016/j.cemconcomp.2013.04.010

[14] Baláz, P. 2000. Extractive metallurgy of activated minerals. Elsevier, Amsterdam, 278.

[15] Juhász, A. Z.; Opoczky, L. 1990. Mechanical Activation of Minerals by Grinding. Akadémiai Kiadó - Ellis. Horwood Ltd Publishers.Budapest Chichester 